\title{
Electrolytic and hemogasometric parameters for female agoutis (Dasyprocta prymnolopha Wagler, 1831) raised in captivity
}

\author{
Parâmetros eletrolíticos e hemogasométricos para cutias fêmeas \\ (Dasyprocta prymnolopha Wagler, 1831) criadas em cativeiro
}

\author{
Marta Silva Muniz ${ }^{1} \oplus$, Artur da Nóbrega Carreiro² $\oplus^{\oplus}$, Erica Emerenciano Albuquerque ${ }^{2} \odot$, \\ João Augusto Rodrigues Alves Diniz ${ }^{3} \odot$, Joyce Galvão de Souza² ${ }^{\circ}$, \\ Danilo José Ayres de Menezes ${ }^{4} \odot$, Antônio Fernando de Melo Vaz ${ }^{2 \star}$ ৫)
}

\begin{abstract}
Agoutis (Dasyprocta prymnolopha, WAGLER 1831) have been studied in captivity as a potential source of meat for rural populations in Brazil, as a way of providing low-cost protein and easing hunting pressures in local communities. However, little is known about their physiological blood markers, which are crucial for animal husbandry and effective welfare management. This study provides hemogasometric and ionic venous parameters for female agoutis raised in captivity in the drylands of Brazil. Venous blood samples were collected from six females and analyzed for dissolved gases and ions in the blood. Hemogasometric parameters, especially base excess and anion gap were generally heterogenous, while ions varied little among individuals. Moreover, we observed high chlorine values and negative base excess values, which suggest that some animals might be implementing compensatory mechanisms for ion imbalances. We provide a preliminary note on agouti venous gases and ions, while reiterating the importance of the clinical context and in-house parameter definition to maximize accuracy.
\end{abstract}

KEYWORDS: Blood gases; Ionogram; Wild animal husbandry.

RESUMO: Cutias (Dasyprocta prymnolopha, WAGLER 1831) têm sido estudadas em cativeiro como uma fonte potencial de carne para populaçóes rurais no Brasil, como uma forma de fornecer proteína de baixo custo e aliviar as pressóes de caça nas comunidades locais. No entanto, pouco se sabe sobre seus marcadores sanguíneos fisiológicos os quais são cruciais para a criação animal e o manejo eficaz do bem-estar. Este estudo fornece parâmetros hemogasométricos e iônicos venosos para cutias fêmeas criadas em cativeiro em regióes áridas do Brasil. Amostras de sangue venoso foram coletadas de seis fêmeas e analisadas para gases dissolvidos e íons no sangue. Os parâmetros hemogasométricos, especialmente o excesso de base e o anion gap, foram heterogêneos, enquanto os íons variaram pouco entre os indivíduos. Além disso, altos valores de cloro e valores negativos de excesso de base foram observados o que sugere que alguns animais podem estar desenvolvendo mecanismos compensatórios para desequilíbrios iônicos. Um perfil preliminar sobre gases e íons venosos de cutias foi fornecido, ao mesmo tempo, destaca-se a importância do contexto clínico e da definiçáo interna dos parâmetros para maximizar a precisão.

PALAVRAS-CHAVE: Gases sanguíneos; Ionograma; Criação de animais selvagens.

\section{INTRODUCTION}

Agouti (Dasyprocta prymnolopha) is a South American rodent of emerging zootechnical value, as it is already traditionally hunted by rural populations and exhibits qualities favorable to domestication such as docility, a relatively short reproductive cycle and easy breeding in captivity (JONES; GARCIA, 2020; RIBEIRO et al., 2008a, b). Some studies have already aimed at clarifying the reproductive, nutritional and morphophysiological characteristics of the agouti to facilitate husbandry and meat production (JOHN; JONES, 2020; LUCENA et al., 2014; GUIMARÁES et al., 2011;

${ }^{1}$ Molecular Biology Department, Center for Exact and Natural Sciences, Federal University of Paraíba, João Pessoa, Paraíba, Brazil.

${ }^{2}$ Academic Unit of Veterinary Medicine, Center for Health and Rural Technology, Federal University of Campina Grande, Patos, Paraíba, Brazil.

${ }^{3}$ Animal Science Department, Center for Agricultural Sciences, Federal University of the Semi-Arid Region, Mossoró, Rio Grande do Norte, Brazil.

${ }^{4}$ Morphology Department, Federal University of Rio Grande do Norte, Natal, Rio Grande do Norte, Brazil.

*Corresponding author: antonio.melo@ufcg.edu.br

Received: 04/03/2021. Accepted: 20/04/2021 
CAVALCANTE et al., 2006), which may ease hunting pressure and meet the demand for a potentially more accessible source of protein for isolated rural communities (NUNES et al., 2019).

The task of raising agoutis in captivity requires detailed understanding of their physiology to inform best practices in husbandry and welfare. Blood markers are particularly important in health monitoring, as they guide clinical decisions and reveal sub-clinical illness. Thus, it is imperative that veterinarians have access to full hematological and biochemical profiles. Among the clinical markers of health, blood gases and ions are crucial for understanding fluid and electrolyte regulation. Variables such as $\mathrm{CO}_{2}$ and bicarbonate influence blood $\mathrm{pH}$, thus controlling the chemical environment in which physiological reactions occur (FOY; DE MORAIS, 2017; KAAE; DE MORAIS, 2008). Meanwhile, ions in the blood contribute to the overall charges and are required for several body functions, such as osmoregulation, enzyme activity, cell communication, hormonal regulation, and neurotransmission (MANNING, 2001; SCHAER, 2008). For this purpose, cell counts and blood biochemistry parameters have been reported (CONDE JÚNIOR et al., 2012; RIBEIRO et al., 2008a, b), but there are no reported values for certain ions, nor a hemogasometric profile, to the best of our knowledge. This study aimed to provide physiological values for hemogasometric parameters, as well as sodium, potassium, chlorine and total calcium levels in the blood of captive female agoutis.

\section{MATERIAL AND METHODS}

The procedures described here were authorized by the Research Ethics Committee of the Federal University of Campina Grande (Protocol 035-2016) and the Brazilian Institute for the Environment via the Biodiversity Authorization and Information System (SISBio) (Protocols $N^{\circ}$ 45046-1 and 47944-1).

Six adult females were kept under homogeneous handling conditions, in natural light and ventilation. They had access to water and pelleted horse feed ad libitum and occasionally to tropical fruits. Their health status was assessed by daily clinical observations that included measuring rectal temperature, heart and respiratory rates, inspection of mucous membranes, presence of ectoparasites, and inspection of the external genitalia associated with hematological tests (data not shown) at the time of blood sampling for gasometric and electrolyte analysis. For sample collection, animals were mechanically restrained, as recommended by Pachaly et al. (2001). Venous blood samples were collected from the inguinal portion of the lateral saphenous vein in $1-\mathrm{mL}$ lithium-heparin syringes. Samples were sent to the Laboratory of Clinical Pathology, Veterinary University Hospital of the Federal University of Campina Grande (UFCG) in styrofoam boxes with ice for analysis. Hemogasometry of heparinized whole blood was performed with an automated hemogasometer (AGS 22, Drake, Brazil), where values of partial pressure of oxygen $\left(\mathrm{pO}_{2}\right)$, partial pressure of carbon dioxide $\left(\mathrm{pCO}_{2}\right)$ and $\mathrm{pH}$ were measured through specific electrodes. Bicarbonate was determined by the Henderson-Hasselbalch equation using the values of $\mathrm{pH}$ and partial $\mathrm{CO}_{2}$ pressure measured. Additional parameters were calculated using the equipment's software. Heparinized plasma was then obtained by centrifugation at $700 \mathrm{~g}$ for 10 minutes, and kept at $-20^{\circ} \mathrm{C}$. Electrolytes (sodium, potassium, chlorine, and total calcium) were measured through specific electrodes in an electrolyte analyzer (Maxion, China). The anion gap was calculated using the values of sodium, potassium, chlorine and bicarbonate ions $\left[\mathrm{AG}=\left(\mathrm{Na}^{+}+\mathrm{K}^{+}\right)-\left(\mathrm{Cl}^{-}+\mathrm{HCO}_{3}^{-}\right)\right]$. Blood gas values obtained were then adjusted according to hemoglobin and temperature of each animal.

Variables were tested for normality by the D'Agostino $\&$ Pearson test with a 5\% significance level. Data considered normal were expressed as mean \pm standard deviation. The reference interval represents the $95 \%$ confidence interval of the sample population and was calculated using Graph Pad Prism 5.1 software (San Diego, CA, USA).

\section{RESULTS AND DISCUSSION}

Hemogasometry parameters varied between samples (Table 1). Moreover, both the $\mathrm{BE}$ and the anion gap varied greatly among individual animals $(-5.14 \pm 5.34 \mathrm{mmol} / \mathrm{L}$ and $4.97 \pm 7.47 \mathrm{mmol} / \mathrm{L}$, respectively). These results yielded a negative BE interval $(-10.75-0.46)$ and revealed different strategies for adjusting the overall charges. In contrast, ionic levels were very consistent between individuals, a feature reflected in their generally narrow confidence intervals.

Table 1. Whole-blood hemogasometry and plasma ions in venous samples of Dasyprocta prymnolopha.

\begin{tabular}{|c|c|c|c|}
\hline & Mean \pm SD & Median & RI (CI 95\%) \\
\hline $\mathrm{pH}$ & $7.33 \pm 0.08$ & 7.34 & $7.24-7.41$ \\
\hline $\mathrm{pCO}_{2(\mathrm{mmHg})}$ & $37.22 \pm 7.86$ & 34.00 & $26.97-45.46$ \\
\hline $\mathrm{pO}_{2(\mathrm{mmHg})}$ & $31.67 \pm 5.92$ & 31.50 & $25.45-37.88$ \\
\hline $\mathrm{HCO}_{3}^{-}(\mathrm{mmol} / \mathrm{L})$ & $19.79 \pm 4.82$ & 19.50 & $14.73-24.84$ \\
\hline $\mathrm{BE}_{(\mathrm{mmol} / \mathrm{L})}$ & $-5.14 \pm 5.35$ & -5.00 & $-10.75-0.46$ \\
\hline sat $\mathrm{O}_{2(\%)}$ & $51.64 \pm 14.66$ & 55.50 & $36.26-67.02$ \\
\hline $\mathrm{TCO}_{2(\mathrm{mmo} / \mathrm{L})}$ & $20.87 \pm 4.98$ & 20.50 & $15.64-26.10$ \\
\hline $\mathrm{K}^{+}{ }_{(\mathrm{mmol} / \mathrm{L})}$ & $3.06 \pm 0.49$ & 2.94 & $2.54-3.56$ \\
\hline $\mathrm{Na}^{+}{ }_{(\mathrm{mmol} / \mathrm{L})}$ & $146.4 \pm 2.62$ & 146.3 & $143.7-149.2$ \\
\hline $\mathrm{Cl}^{-}{ }_{(\mathrm{mmol} / \mathrm{L})}$ & $124.7 \pm 10.42$ & 121.3 & $113.8-135.7$ \\
\hline $\mathrm{Ca}^{++}{ }_{(\mathrm{mmol} / \mathrm{L})}$ & $1.74 \pm 0.20$ & 1.75 & $1.52-1.96$ \\
\hline$A G_{(\mathrm{mmol} / \mathrm{L})}$ & $4.97 \pm 7.49$ & 7.87 & $-2.86-12.81$ \\
\hline
\end{tabular}

$\mathrm{BE}=$ base excess; $\mathrm{AG}=$ anion gap; sat $\mathrm{O}_{2}=\mathrm{O}_{2}$ saturation; $\mathrm{SD}=$ standard deviation; $\mathrm{RI}(95 \% \mathrm{Cl})=$ reference interval represents the $95 \%$ confidence interval of the sample population. 
In addition, sodium was the element with the smallest variation $(146.28 \pm 2.75 \mathrm{mmol} / \mathrm{L})$.

The hemogasometric parameters evaluated are very sensitive to pre-analytical variations, such as the stress caused by handling, syringe material and conditions of transportation (BAIRD, 2013). Particularly, values described in this study may be affected by handling stress, as agoutis are still undomesticated and thus subjected to stress responses to parameter changes when restrained (JONES; GARCIA, 2019; CONDE JÚNIOR et al., 2012). Additionally, heterogeneity was to be expected within a small sample size. The whole-blood venous samples revealed heterogeneous hemogasometric parameters coupled with homogeneous anionic parameters, suggesting different compensation stages involving bicarbonate as a key element. In particular, the negative BE may reflect reduced bicarbonate values when compared to other mammalian species, since its calculation includes bicarbonate, hemoglobin and $\mathrm{pH}$ as variables. Thus, low bicarbonate values coupled with negative BEs may be part of the physiological mechanism for balancing the overall charges through the adjustment of alkaline components (FOY; MORAIS, 2017). However, it should be noted that $\mathrm{BE}$ is a dynamic parameter and its physiological values for $D$. prymnolopha are unknown and therefore, our results may still be within normality. As another tool for the maintenance of physiological (neutral) charges, anion gap values followed a similar pattern. Low BE and bicarbonate values appeared in contrast to the relatively high chlorine values, which should result in unchanged anion gap values, as negative charges are adjusted (KAAE; MORAIS, 2008). This parameter measures the negative gap in overall charges - considering that not all ions are measured - and it is especially relevant for assessing states and causes of metabolic acidosis (SEIFTER, 2020; KAAE; DE MORAIS, 2008).

As for clinical interpretation, it should be noted that partial $\mathrm{O}_{2}$ pressure $\left(\mathrm{pO}_{2}\right)$ in venous blood is of little relevance, since it reveals the state of tissue oxygenation and requires knowledge of oxygen levels in arterial blood (MARTIN; PRIESTAP, 2017). Clinically, the hemogasometric analysis of venous blood carries two useful indicators of acid-base imbalance defined by $\mathrm{pH}$ : bicarbonate and carbon dioxide, as both indicate acid-base balance control (WEISER, 2012). In addition, the best assessment of the acid-base and electrolyte balance requires a correlation between venous and arterial samples. Nevertheless, the literature reveals an active search for reliable methods that can predict arterial data from its venous counterparts, as venous blood collection poses less discomfort to the patient and less risk of injuries (MARTIN; PRIESTAP, 2017; RAGHAV et al., 2015).

Regarding ionic levels, values were very consistent among individual animals. Sodium levels were similar to those reported in the literature for domesticated mammals and laboratory rodents (GOFF, 2015; QUESENBERRY; CARPENTER, 2003). Among the cations, sodium is the most abundant in the extracellular compartment and thus the most relevant for charge adjustment in this context (KAAE; DE MORAIS, 2008). Its levels are regulated by the kidney along with potassium levels, and changes in these cations are usually associated with neurological, muscular, and cardiac dysfunction because of their role in synaptic polarization (SCHAER, 2008). As for calcium, our measurements were consistent with the findings of Ribeiro et al. (2008b) for female Dasyprocta sp. This cation is relevant for a range of cell-level functions, such as cell signaling, enzyme activity, and muscle contraction (MANNING, 2001), and alterations in its levels may be related to diverse etiologies including malabsorption, vitamin $\mathrm{D}$ deficiency, and hypoparathyroidism (SCHAER, 2008).

In contrast to the cations, chlorine was found in amounts higher than those described for other species of mammals and even for female agoutis at different ages (RIBEIRO et al., 2008b). The high chlorine, coupled with low bicarbonate, may be part of the compensation mechanism in the anion/cation balance by adjusting the composition of charges present in the fluid compartment (SEIFTER; CHANG, 2017). Furthermore, the fact that chlorine was consistently high indicates that it may be a temporary circumstance due to high concentrations of this element in the drinking water, which is common in water reservoirs in northeastern Brazil during long periods of drought.

\section{CONCLUSIONS}

Our findings provide a preliminary picture of venous gases and ions in female agouti, and represent useful information for later disease research. However, they highlight the ultimate importance of the clinical context and in-house parameter definition to maximize the homogeneity of both pre-analytical and analytical methods applied to the samples, as well as to account for environmental factors, such as the type of rearing and local weather. For the purpose of agouti health monitoring, our results may not be used as clinical reference. Studies with a greater number of animals, expansion of the literature and comparison between different laboratories are necessary to obtain reliable reference intervals that accurately reflect the electrolytic and acid-base state of D. prymnolopha, as well as other animals with poorly understood physiology.

\section{ACKNOWLEDGMENTS}

We would like to thank the staff at UFCG's Animal Morphology Department and Clinical Pathology Laboratory for kindly contributing to the logistics and management of the tools necessary for this study. 


\section{REFERENCES}

BAIRD, G. Preanalytical considerations in blood gas analysis. Biochemia Medica, v. 23, n. 1, p. 19-27, 2013.

CAVALCANTE, R. R. et al. Peso pós-parto, frequência e prevalência do tipo de parto de cutias (Dasyprocta sp.) criadas em cativeiro. Ciência Animal Brasileira, v. 6, p. 67-70, 2006.

CONDE JÚNIOR, A. M. et al. Morphological and morphometric characterization of agoutis' peripheral blood cells (Dasyprocta prymnolopha, Wagler, 1831) raised in captivity. Microscopy Research and Technique, v. 75, n. 3, p. 374-378, 2012.

FOY, D. S.; DE MORAIS, H. A. A Quick Reference on Metabolic Alkalosis. Veterinary Clinics of North America: Small Animal Practice, v. 47, n. 2, p. 197-200, 2017.

GOFF, J. P. Minerals. In: REECE, W. O. et al. Dukes' Physiology of domestic animals. 13. ed. New Jersey: Wiley-Blackwell, 2015.

GUIMARÃES, D. A. et al. Plasma concentration of progesterone and 17B-estradiol of black-rumped agouti (Dasyproctaprymnolopha) during the estrous cycle. Revista de Biologia Tropical, v. 59, n. 1, p. 29-35, 2011.

JOHN, E. N.;JONES, K. R. Evaluation of Unconventional Supplements to the Diet of Intensively Reared Agouti (Dasyproctaleporina) in Trinidad, West Indies. Veterinary Sciences, v. 7, n. 3, p. 108, 2020.

JONES, K. R.; GARCIA, G. W. Understanding blood and serum values of the agouti (Dasyprocta spp.): A rodent of the Neotropics with the potential to be domesticated. Tropical Agriculture, v. 96, n. 1, 2020.

KAAE, J.; DE MORAIS, H. A. Anion Gap and Strong lon Gap: A Quick Reference. Veterinary Clinics of North America: Small Animal Practice, v. 38, n. 3, p. 443-447, 2008.

LUCENA, L. U. et al. Performance and nutrient digestibility of diets containing babassu ("Orbignya speciosa") products for agoutis ("Dasyproctaprymnolopha" Wagler, 1831) in captivity. Revista Brasileira de Saúde e Produção Animal, v. 15, n. 1, p. 39-47, 2014.

MANNING, A. M. Electrolyte Disorders. Veterinary Clinics of North America: Small Animal Practice, v. 31, n. 6, p. 1289-1321, 2001.

MARTIN, C.M.; PRIESTAP, F. Agreement between venous and arterial blood gas analysis of acid-base status in critical care and ward patients: a retrospective cohort study. Journal of Anesthesia, v. 64, n. 1l, p. 1138-1143, 2017.
MARTIN, C. M.; PRIESTAP, F. In reply: the agreement between venous and arterial blood gas in critical care and ward patients: is there a need to stratify for shock? Canadian Journal of Anesthesia, v. 65, n. 6, p. 738-738, 2018.

NUNES, A. V. et al. Wild meat sharing among non-indigenous people in the southwestern Amazon. Behavioral Ecology and Sociobiology, v. 73, n. 2, p. 26, 2019.

PACHALY, J. R. et al. Order Rodentia (rodents). In: FOWLER, M. E.; CUBAS, Z. S. (Ed). Biology, medicine, and surgery of South American wild animals. lowa: lowa State University Press, 2001.

QUESENBERRY, K. E.; CARPENTER, J. W. Ferrets, Rabbits, and Rodents Clinical Medicine and Surgery. 2. ed. St. Louis: Saunders, 2003. p. 243-290.

RACHAV, R. et al. Analysis of Arterial and Venous Blood Gases in Healthy Gyr Falcons (Falco rusticolus) Under Anesthesia. Journal of Avian and Medicine Surgery, v. 29, n. 4, p. 290-297, 2015

RIBEIRO, E. E. A. et al. Hemograma e proteinograma de cutias (Dasyprocta sp.) hígidas, criadas em cativeiro: influência do sexo e da idade. Arquivo Brasileiro de Medicina Veterinária e Zootecnia, v. 60, п. 5, p. 1123-1127, 2008a.

RIBEIRO, E. E. A. et al. Níveis iônicos e enzimáticos de cutias (Dasyprocta sp.) hígidas, criadas em cativeiro, influência do sexo e da idade. Influence of gender and age. Arquivo Brasileiro de Medicina Veterinária e Zootecnia, v. 60, n. 3, p. 651-655, 2008b.

SCHAER, M. Therapeutic Approach to Electrolyte Emergencies. Veterinary Clinics of North America: Small Animal Practice, v. 38, n. 3, p. 513-533, 2008

SEIFTER, J. L. Anion-gap metabolic acidemia: case-based analyses. European Journal of Clinical Nutrition, v. 74, n. 1, p. 83-86, 2020.

SEIFTER, J. L.; CHANG, H.-Y. Extracellular Acid-Base Balance and Ion Transport Between Body Fluid Compartments. Physiology, v. 32, п. 5, p. 367-379, 2017.

WEISER, G. Laboratory evaluation of acid-base disorders. In:THRALL, $M$. A. et al. (Ed) Veterinary hematology and clinical chemistry. 2. ed. lowa: Wiley-Blackwell, 2012. p. 393-400. 